\title{
Persepsi Ibu Terhadap Obesitas pada Anak Sekolah Dasar
}

\section{Perception of mothers about obesity In elementary school Students}

\begin{tabular}{l} 
Emy Leonita $*$, Nopriadi $^{* *}$ \\
\hline * Staf Pengajar STIKes Hang Tuah Pekanbaru \\
** Staf Pengajar PSIKM Fakultas Kedokteran Unand
\end{tabular}

\begin{abstract}
Abstrak
Obesitas merupakan dilema kesehatan yang berisiko penyakit. Beberapa faktor penyebab obesitas pada anak selain genetik, pola makan berlebihan dan pola aktivitas yang kurang. Hal tersebut diduga adanya kesalahan persepsi orangtua terutama ibu terhadap obesitas sehingga berdampak pada pengaturan pola makan dan pola aktivitas anak. Tujuan penelitian ini adalah untuk Menggali persepsi ibu terhadap anak obesitas. Penelitian ini menggunakan metode kualitatif dengan wawancara mendalam kepada ibu, wali kelas, guru UKS dan petugas dinas kesehatan. Observasi lingkungan sekolah dan rumah, food record dan activity record dilakukan terhadap anak. Untuk keabsahan data dilakukan triangulasi metode dan sumber. Beberapa kesalahan persepsi pada ibu yang mengakibatkan kesalahan dalam mengatur pola makan dan aktivitas pada anak obesitas antara lain adalah ibu beranggapan wajar saja balita gemuk, bila dewasa/remaja akan kurus dengan sendirinya. Ibu beranggapan makanan lokal seperti bakso, sate, siomay dan aneka mie bukan termasuk fast food. Ibu selalu mendorong anak untuk tambah porsi makan dan cenderung menuruti pola makan berlebihan karena faktor ketidaktegaan. Ibu tidak memaksakan anak untuk beraktivitas dan olahraga karena menganggap anak sudah lelah dengan jadwal yang padat di sekolah. Berenang menurut ibu bukan pilihan olahraga yang tepat pada anak obesitas, karena setelah berenang memicu rasa lapar pada anak. Diperlukan suatu strategi pendekatan promosi terhadap orangtua dan anak dalam penanggulangan obesitas
\end{abstract}

Kata Kunci : obesitas, persepsi ibu, pola makan anak dan pola aktivitas anak

\begin{abstract}
Obesity is a health problem that brings risk to diseases. Some factors that cause obesity in children include genetics, excessive eating and low physical activities. It is presumed there is wrong perception of mothers about obesity that affects in the arrangement of eating and physical activity pattern in children. The study used qualitative method. The purpose of this study is to elaborate the perception of mothers about obese children. Data were obtained through indepth interview with mothers, homeroom teachers, teachers of school health and staff of the health office. Observation was made to school and house environment, food record and activity record of children. Method and source triangulation was made to maintain data validity. Some mistakes in the perception of mothers result in mistakes in managing eating pattern and physical activity of obese children such as mothers found it $O K$ if underfives were fat because when they became teenagers/adults their body would be back to normal. Mothers thought that local foods such as meatball, satay, siomay and any kind of noodle did not belong to fast foods. Mothers tended to encourage children to have more portion and excessive consumption because they did not have the heart to stop the children from eating. Mothers did not recommend children to do physical activities since they considered that children were already tired with tight school activities. Swimming, according to mothers, was not a good choice for obese children because it would ignite hunger in children. It was necessary to have a strategic approach of promotion for parents and children in order to prevent obesity.
\end{abstract}

Keywords: obesity, perception, eating pattern, physical activity

\footnotetext{
${ }^{1}$ Alamat Korespondensi: Emy Leonita, STIKes Hang Tuah Pekanbaru, Ketua Prodi IKM, Jalan Mustafa Sari No 5

Tangkerang Selatan Pekanbaru Riau, Hp : 081276093093, email : leonitaemy@ yahoo.com
} 


\section{Pendahuluan}

Angka obesitas pada anak usia 6-17 tahun di Amerika dalam tiga dekade terakhir meningkat dari 7,6-10,8\% menjadi $13-14 \%$. Prevalensi overweight dan obesitas pada anak usia 6-8 tahun di Rusia adalah 6-10\%, di Cina sebesar 3,4-3,6\% dan di Singapura prevalensi obesitas pada anak sekolah meningkat dari 9\% menjadi 19\% (Syarif, 2003). Di Indonesia, perubahan gaya hidup yang menjurus ke westernisasi mengakibatkan pola makan masyarakat yang merujuk pada pola makan tinggi kalori, lemak dan kolesterol. Jumlah obesitas anak di Indonesia tidak sedikit, seperti temuan di Bali tahun 2002 yang memperlihatkan prevalensi obesitas pada anak sekolah dasar di Kota Denpasar sebesar 13,6\% dan prevalensinya lebih tinggi pada sekolah dasar swasta $(18,2 \%)$ dibandingkan sekolah dasar negeri $(12,4 \%)$ (Padmiari,2002). Angka ini meningkat bila dibandingkan dengan penelitan di Yogyakarta tahun 1998 yang menemukan prevalensi kegemukan pada anak sekolah dasar sebesar 9,5\% (Widjajanto,1998), dan di Jakarta Timur pada tahun 2003 angkanya mencapai 27,5\% (Syarif, 2003).

Kota Pekanbaru merupakan ibu kota Propinsi Riau yang masuk dalam katagori kota besar (perkotaan), sehingga tidak menutup kemungkinan prevalensi obesitas anak SD pada daerah tersebut tinggi. Julia (2008) mengatakan bahwa obesitas anak pada daerah urban (perkotaan) meningkat pada usia remaja daripada daerah pedesaan. Obesitas pada usia tersebut lebih tinggi bila dibandingkan dengan hasil observasi yang dilakukan di Cina (Julia, 2008). Penelitian lain mengatakan bahwa keadaan tersebut berkaitan dengan menurunnya persediaan makanan rendah kalori atau menurunnya jalan masuk ke fasilitas bermain (Behrman et.al, 2002).

Anjuran mengevaluasi kegemukan sejak dini bukannya tanpa dasar. Obesitas pada masa anak berisiko mengalami obesitas di masa dewasa (30-60\%) (Maffeis et.al, 2000). Dalam sebuah penelitian pada tahun 2003 didapatkan bahwa 1/3 anak yang obesitas saat prasekolah menjadi obesitas pada saat dewasa, dan $1 / 2$ anak yang obesitas pada masa sekolah menjadi obesitas pada masa dewasa (Mexitalia, 2005). Dalam jangka panjang maupun jangka pendek obesitas berisiko mengalami berbagai penyakit antara lain seperti diabetes mellitus tipe 2, gangguan pernafasan, penyakit kardiovaskuler, gangguan orthopedik dan lain-lain. Penelitian di Yogyakarta yang mengikuti perkembangan anak SD hingga SMP selama 2 tahun menemukan bahwa perubahan status obesitas pada siswa-siswi tersebut menjadi nonobesitas sangat kecil (Huriyati,2006).

Beberapa faktor yang menyebabkan obesitas antara lain adalah faktor genetik dan lingkungan. Seseorang tentu saja tidak dapat mengubah pola genetiknya. Namun mereka dapat mencegah dan mengelola obesitas dengan mengendalikan faktor lingkungan, antara lain mengubah pola makan dengan meminimalisasi makanan tinggi lemak dan kalori. Anak-anak usia sekolah mempunyai kebiasaan mengkonsumsi makanan cepat saji (junk foods dan fast foods) yang umumnya mengandung energi tinggi karena 40-50\% dari junk food tersebut berasal dari lemak, begitu juga kebiasaan mengkonsumsi makanan cemilan yang banyak mengandung gula sambil menonton televisi yang mengakibatkan terjadi peningkatan asupan energy (Syarif, 2003). Selain faktor nutrisi, aktivitas fisik yang kurang merupakan faktor predisposisi terjadinya obesitas.

Modifikasi pengelolaan pola makan dan aktivitas tersebut sebaiknya dilaksanakan secara multidisiplin (medis dan nonmedis) dengan mengikutsertakan keluarga, terutama ibu karena secara umum perawatan anak bergantung pada ibunya. Masa anak merupakan waktu yang tepat untuk menanamkan perilaku dan kebiasaan kesehatan yang baik.

Di masyarakat ada kebanggaan ketika anak mereka yang obesitas dipuji karena gemuk dan lucu. Bahkan mereka beranggapan anak yang gemuk/obesitas adalah anak yang sehat dan berkecukupan gizi. Banyak kasus obesitas yang terjadi pada anak-anak dianggap oleh orangtua sebagai hal yang biasa dan merupakan gambaran anak sehat. Bahkan 
dalam persepsi ibu, anak yang mengalami obesitas adalah kelebihan berat badan saja dan bukan obesitas (Baugham et.al, 2006). Padahal persepsi orangtua yang berkaitan dengan nutrisi seperti pemilihan makanan tinggi lemak dan kalori merupakan salah satu faktor pendukung terjadi obesitas. Kecenderungan anak untuk menyukai makanan tersebut tergantung pada ketersediaan makanan di rumah. Ada hubungan bermakna $(p<0,05)$ antara frekuensi makan di rumah dengan status obesitas pada anak (Podojoyo, 2005), keterjangkauan dan efek pajanan terhadap kesukaan pada makanan tertentu, begitu pula peranan orangtua dalam memutuskan pemilihan makanan (Subardja, 2005). Dengan demikian, persepsi orangtua sangat penting dalam pencegahan dan pengelolaan obesitas pada anak.

Dua hal penting dalam pengelolaan obesitas pada anak adalah pencegahan dan pengobatan. Walaupun keberhasilannya samasama memerlukan peran serta multidisiplin ilmu kesehatan dan nonkesehatan bahkan peran aktif masyarakat maupun pemerintah, tetapi secara ekonomis pencegahan primer maupun sekunder tetap lebih menguntungkan dibandingkan dengan pengobatannya. Pemahaman pola makan dan pola aktivitas pada anak obesitas secara individual penting dalam merencanakan pengelolaan di klinik (Subardja, 2005). Dengan demikian pemahaman orangtua terutama ibu dapat mencegah terjadinya obesitas pada anakanaknya.

Melihat beban berat pemerintah dalam bidang kesehatan, perlu dipikirkan bersama untuk pencegahan dan penanggulangan obesitas dengan strategi yang lebih efektif dan efisien. Salah satu strategi tersebut adalah dengan melibatkan orangtua terutama ibu sebagai strategi pendekatan promosi kesehatan melalui anak yang mengalami obesitas. Dengan demikian, penelitian ini diharapkan dapat menggali mengapa obesitas terjadi pada anak bila dipandang pada persepsi ibu.

\section{Metode}

Penelitian ini menggunakan metode kualitatif dengan rancangan pendekatan fenomenologi. Pemilihan metode kualitatif pada penelitian ini adalah untuk meneliti fenomena yang tidak dapat diteliti melalui penelitian secara kuantitatif sebelumnya (Moleong, 2008). Peneliti fenomena tidak hanya mencari perbedaan yang terjadi pada seseorang, tetapi mencari apa yang membuat perbedaan itu terjadi (Morse, 1992).

Penelitian dilaksanakan pada 2 sekolah dasar negeri dan satu sekolah dasar swasta yang ada di Kota Pekanbaru Propinsi Riau. Populasi dalam penelitian ini adalah orangtua yaitu ibu dari anak obesitas kelas 5 dan 6 pada sekolah dasar yang ada di Kota Pekanbaru. Ibu menjadi informan utama dalam penelitian ini. Anak obesitas, guru pembimbing UKS, wali kelas, dan petugas dinas kesehatan Kota Pekanbaru merupakan informan pendukung dalam rangka melengkapi data ataupun informasi yang diperlukan dalam penelitian ini, sekaligus untuk triangulasi. Jumlah subjek penelitian yang menjadi informan utama dan informan pendukung dalam penelitian ini adalah 23 orang, dengan rincian 8 orang ibu, 8 orang anak, 2 orang pembimbing UKS, 4 orang wali kelas dan 1 orang petugas dinas kesehatan Kota Pekanbaru.

Pengambilan data dalam penelitian ini dilakukan dengan cara: 1) Wawancara mendalam (indepth interview) kepada informan inti (ibu) dan informan pendukung (pembimbing UKS, wali kelas dan petugas dinas kesehatan). Proses pengumpulan informasi menggunakan panduan wawancara yang bersifat terbuka. Masing-masing kelompok informan diberikan pertanyaan yang berbeda sesuai dengan informasi apa saja yang ingin diperoleh, 2) Food record berisi tentang format jadwal makan dan apa saja yang dimakan anak selama $3 \times 24$ jam serta Activity Record yaitu berisi tentang apa saja kegiatan yang dilakukan anak selama satu hari beserta durasi waktunya selama $3 \times 24$ jam. Kedua format tersebut diisi langsung oleh anak, 3) Observasi dilakukan langsung yaitu kondisi sekolah (ketersediaan kantin disekolah, jenis jajanan, ketersediaan fasilitas 
olahraga dan lapangan bermain), serta kegiatan anak ketika di sekolah.

Proses analisis data yang dilakukan dalam penelitian ini antara lain adalah merekapitulasi atau mengumpulkan semua informasi yang diperoleh dari lapangan (wawancara mendalam, food record, activity record dan observasi), selanjutnya dibuat transkrip, kemudian dibuat koding untuk memudahkan pencarian sumber informasi. Setelah itu, peneliti melakukan katagorisasi informasi, melakukan interpretasi terhadap informasi, penyajian data dan menarik kesimpulan dalam bentuk laporan penelitian.

\section{Hasil Dan Pembahasan}

\section{Persepsi Orangtua terhadap Obesitas pada Anak}

Persepsi ibu dalam penelitian ini adalah suatu bentuk penilaian ibu terhadap obesitas pada anak. Beberapa persepsi awam yang diduga berkembang di masyarakat antara lain anak obesitas dipersepsikan sebagai anak sehat dan lucu, obesitas merupakan lambang kemakmuran, penampilan anak obesitas menarik serta adanya kebanggaan orangtua mempunyai anak gemuk. Sebelum menggali beberapa persepsi ibu, diketahui pengetahuan ibu yang melatarbelakangi munculnya penilaian terhadap obesitas. Pegetahuan tersebut adalah bagaimana ibu mengetahui ciri-ciri anak sehat, obesitas pada anak serta dampak yang ditimbukan oleh obesitas.

\section{Anak sehat}

Semua ibu dari anak obesitas mengetahui anak sehat itu adalah anak yang tidak gampang sakit, tidak ada hambatan dalam beraktivitas, aktif bergerak, tidak malas, cekatan, cukup berolahraga, cukup gizi, keseimbangan makan dengan aktivitas, keseimbangan berat badan dengan umur, serta mampu mengikuti pelajaran di sekolah dan memiliki pola pikir yang berkembang.

Beberapa ungkapan dari ibu mengenai kondisi sehat bila ditarik kesimpulan hampir mendekati dengan pengertian kesehatan menurut UU Kesehatan adalah keadaan sejahtera dari badan, jiwa dan sosial yang memungkinkan setiap orang hidup produktif secara sosial dan ekonomi (UU Kesehatan
1992, 2000). Lebih lanjut dikatakan banyak orang yang menikmati suatu kondisi sehat, walau orang lain mungkin memandang kondisi tersebut sebagai kondisi yang tidak sehat (Mc Kenzie et.al, 2007). Jadi, setiap orang, atau dalam penelitian ini, ibu-ibu melihat kondisi sehat pada anak dengan pandangan berbeda-beda dengan maksud yang sama.

\section{Obesitas pada anak}

Setiap ibu memiliki persepsi yang berbeda tentang kondisi obesitas pada anak. Sebagian ibu tidak suka dengan obesitas, karena menurut ibu tidak enak dilihat. Berat badan yang berlebih itu disebabkan kelebihan makanan berlemak, banyak ngemil, dan faktor keturunan. Walaupun tidak setuju dengan obesitas, sebagian ibu menganggap wajar saja bila kondisi gemuk itu dialami oleh balita karena belum banyak bergerak dan banyak minum susu, serta di atas usia balita dan remaja anak akan mengalami penurunan berat badan dikarenakan banyak bergerak.

Pendapat beberapa ibu tentang kewajaran anak balita menjadi obesitas tidak sesuai dengan kondisi saat ini yaitu meningkatnya prevalensi obesitas yang terjadi sejak usia balita. Di Amerika saja obesitas 1-2 tahun sekitar $8 \%$ menjadi obesitas dewasa (Hidayati et.al, 2005), begitu juga yang ditemukan pada data rekam medik kasus baru yang datang ke poliklinik anak bagian IKAFKUI RSUPNCM dalam priode 1995-2000 adalah sebanyak 100 pasien, 35\% diantaranya adalah balita (Syarif, 2002). Tentu saja kita harus waspada dengan angka tersebut. Kegemukan pada anak bukanlah terjadi begitu saja menjadi obesitas bila dewasa, namun diperparah oleh kondisi obesitas masa anak terutama balita (Behrman, 2000). Untuk itu skrining dianjurkan pada setiap anak gemuk setelah usia 2 tahun (Syarif, 2002). Hal ini tentu saja berkaitan dengan kemudahan penanggulangan dan pencegahan obesitas sejak dini.

Secara keseluruhan ibu mengetahui bahwa anak termasuk kategori obesitas. Pendapat tersebut sama dengan penelitian di Yogyakarta bahwa orangtua telah dapat membedakan anaknya dalam kategori gemuk 
(Widjajanto, 1998). Hal ini dimungkinkan karena sebagian besar orangtua mempunyai tingkat pendidikan yang tinggi dan kemudahan akses informasi. Penelitian ini berbeda dengan penelitian lain yang mengatakan bahwa terjadi kesalahan penafsiran berat badan anak, hanya sedikit ibu yang memahami bahwa anak mereka adalah obesitas (Baugham, 2006). Dalam penelitian ini, ibu berpendapat tidak ada perbedaan antara anak laki-laki yang gemuk dan anak yang perempuan gemuk, sehingga mengharapkan apabila remaja berat badan anak bisa turun

\section{Dampak obesitas}

Ketidaksetujuan ibu terhadap obesitas dikarenakan kekhawatiran mereka terhadap dampak yang ditimbulkan oleh obesitas antara lain penyakit jantung, diabetes, hipertensi, kesulitan bergerak, kesulitan bernafas, cepat lelah, malas, pergerakan lamban, lecet pada kulit paha, kegagalan khitan, hingga menyebabkan rasa kurang percaya diri. Namun, sebagian ibu menganggap anaknya sehat-sehat saja dan tidak mengalami penyakit akibat obesitas sehingga belum perlu untuk melakukan pengobatan

\section{Gemuk adalah anak sehat dan lucu}

Sebagian besar orangtua sudah memahami penyakit yang ditimbulkan oleh kegemukan, karena itu mereka tidak setuju bila ada anggapan anak gemuk itu adalah anak sehat dan beranggapan merupakan persepsi lama. Namun masih ada anggapan di masyarakat bahwa anak gemuk itu lucu dan menggemaskan.

\section{Gemuk lambang kemakmuran}

Masih adanya anggapan gemuk lambang kemakmuran diakui oleh beberapa informan hanya sebagai ungkapan dan lelucon saja. Mereka menganggap bahwa ungkapan tersebut sekedar menyenangkan hati. Walaupun demikian masih ada juga informan yang setuju dengan ungkapan tersebut, karena gemuk melambangkan sehat yang berarti memperlihatkan kemakmuran.

\section{Penampilan anak gemuk}

Sebagian besar ibu melihat penampilan anak gemuk itu tidak menarik, bahkan mereka mengalami kesulitan untuk "memperbagus" penampilan anak mereka yaitu kesulitan dalam mencari pakaian karena pakaian gampang robek, gampang sempit, dan ukuran anak mereka lebih besar dari ukuran anak seumurnya. Walaupun kesulitan dalam berpakaian/berpenampilan, mereka merasa anak tampak percaya diri dengan kegemukannya karena mereka beralasan banyak juga teman-teman anaknya yang lain berpenampilan serupa (gemuk).

\section{Kebanggaan mempunyai anak gemuk}

Mempunyai anak yang gemuk menjadikan beberapa orangtua sedikit bangga, akan tetapi kebanggaan itu muncul ketika anak baru mulai kelihatan gemuk. Ketika menyadari dampak negatifnya ibu merasa tidak bangga lagi dan terpaksa menerima keadaan tersebut

Persepsi orangtua dalam penelitian ini adalah adanya anggapan bahwa anak gemuk itu anak sehat dan lucu, gemuk melambangkan kemakmuran, penampilan anak gemuk menarik, dan merasa bangga mempunyai anak gemuk. Setiap orangtua berbeda menanggapi pernyataan tersebut, ada yang setuju dan ada pula yang tidak setuju. Sebagian orangtua memahami anak gemuk itu tidak sehat, namun mereka menganggap wajar saja kondisi tersebut terjadi ketika balita dan terpaksa menerima kondisi anak gemuk saat sekarang karena kesalahan pada pola asuh makan dengan selalu merasa tidak tega untuk menolak keinginan anak. Namun orangtua menyesali kondisi tersebut. Perbedaan persepsi tersebut bertentangan dengan penelitian di Yogyakarta yang mengatakan tidak ada keterkaitan antara persepsi ibu dengan status obesitas anak (Widjajanto, 1998) (Pampang, 2007).

Persepsi merupakan salah satu dasar pemahaman ibu berkemungkinan mempengaruhi pesan dalam keluarga terkait dengan pola makan dan pola aktivitas fisik (Eckstein et.al, 2006). Masih adanya perbedaan persepsi awam dengan kesehatan sering menimbulkan masalah dalam melaksanakan program kesehatan (Sarwono, 2007), perbedaan persepsi tersebut juga terutama persepsi yang salah menyebabkan kekeliruan dalam menilai dan 
mengasumsikan sesuatu sesuai dengan harapan (Mulyana, 2007).

\section{Cara ibu mengatur pola makan anak}

Hasil wawancara dengan beberapa orang ibu yang mempunyai anak obesitas yang bersekolah di SD negeri dan SD swasta, yang bekerja dan tidak bekerja, mendapatkan sebagian mereka menganggap pola makan anak sudah teratur yakni makan 3 kali dalam sehari. Menu makanan di rumah ditentukan oleh ibu seperti lauk pauk dan sayur. Ibu tidak mengalami hambatan dalam memberi anak mereka makan, justru anak tidak memilih jenis makanan, malah mereka ngotot untuk menambah makanan dan cenderung marah atau "ngambek" bila tidak dituruti kemauannya. Oleh karena ibu merasa tidak tega dan kasihan, ibu lalu menuruti kemauannya. Nafsu makan berlebihan pada anak obesitas lumrah terjadi. Hal tersebut dikarenakan meningkatnya metabolisme absolut dengan peningkatan ukuran badan, ini menyebabkan anak obesitas lebih banyak makan dibandingkan dengan anak yang normal (Subardja, 2005). Makan yang berlebihan dapat meningkatkan konsumsi energi dan memiliki risiko 3,8 kali menjadi obesitas dibanding dengan konsumsi energikurang karena tidak seimbangnya energi yang dikeluarkan (Podojoyo, 2005). Sama dengan penelitian yang dilakukan di Bogor, pelajar gemuk makan lebih banyak dibandingkan pelajar normal, namun mempunyai aktivitas relatif sama dengan pelajar normal (Dwiriani et.al, 2007).

Selain itu, ibu terpaksa menuruti pemberian pola makan yang berlebihan. Ibu malah sering menawari anak untuk tambah ketika anak menghabisi porsi makannya, sehingga terbentuk pola makan sekarang, yakni pola makan berlebihan. Begitu pula dengan faktor kemanjaan keluarga yang menganggap "anak emas". Beberapa ibu menganggap tidak masalah anak makan berlebihan dan nambah, karena anak dalam masa pertumbuhan yang memerlukan gizi cukup. Pola makan anak yang berlebihan tentunya di awali dengan kebiasaan pola makan di rumah yang umumnya disajikan oleh ibu. Pola kebiasaan makan ibu tergambar dalam menu keluarga dan bila menu yang disajikan ibu merupakan makanan yang tinggi kalori dan lemak, maka akan mengakibatkan terjadinya peningkatan berat badan pada keluarga (Adiningsih, 2002). Kekurangan atau kelebihan asupan energi tergantung peran orangtua dalam kemampuan untuk membeli, ketersediaan bahan makanan dipasar dan produksi serta tingkat pendidikan dan pemahamannya (Pampang, 2007).

Kemampuan orangtua dalam penelitian ini adalah dalam menyediakan uang jajan yang cukup besar pada anak serta ketersediaan jenis makanan fast food lokal di sekolah maupun di luar rumah. Menurut ibu, anak mereka bila di rumah jarang atau bahkan tidak suka makan sayur serta jarang makan fast food. Namun lebih cenderung sering makan cemilan dan jajanan seperti gorengan, sate, siomay, bakso, dan lain-lain. Beberapa ibu menyadari pola makan anak mereka yang berlebihan bisa menambah berat badan anaknya, sehingga mereka pernah berkonsultasi dengan dokter dan ahli gizi dalam mengatur pola makan anak. Namun program yang di laksanakan tidak berjalan sebagaimana mestinya karena kendala dari anak sendiri.

Selain tidak bisa mengendalikan nafsu makan anak, para orangtua mengakui banyak tidak mengetahui dan tidak bisa mengontrol jajanan anak mereka di sekolah (orangtua memberi uang saku yang cukup besar pada anak sebesar Rp.5.000,- s/d Rp.10.000). Pada hal jajanan anak SLTP di sekolah rata-rata Rp. 3.390/hari yang memungkinkan untuk mengkonsumsi western fast food lebih banyak daripada siswa yang jajannya Rp. 1.433/hari (Mahdiah, 2004). Ada juga orangtua yang selalu menanyakan pada anak tentang apa saja yang mereka beli di sekolah. Anak-anak cenderung untuk jajan yang mengenyangkan seperti nasi ayam, nasi soto, mie ayam siomay, dan lain-lain. Kurangnya pengawasan makan anak di sekolah membuat orangtua berkeinginan untuk mengetahui apa saja yang dibeli anaknya.

Penyebab kurangnya pengawasan makan anak di luar rumah tentu saja dipengaruhi oleh beberapa faktor antara lain semakin sempit dan kurangnya informasi kepada orangtua 
terkait dengan perbedaan makanan sehat dan kurang sehat kepada anaknya di samping adanya iklan makanan komersial, serta keterbatasan waktu pertemuan orangtua dengan anak karena pekerjaan (Hesketh et.al, 2005). Bila dilihat dari penelitian ini keterbatasan pertemuan tersebut juga karena waktu anak lebih banyak berada di sekolah sehingga pengawasan / kontrol perilaku anak menjadi semakin berkurang. Bahkan orangtua protes terhadap kebijakan sekolah (negeri dan swasta) yang menurutnya memicu anak menjadi gemuk dan orangtua pernah berfikir agar anaknya tidak usah diberi jajan walau akhirnya merasa tidak tega. Sikap orangtua yang ingin mencegah dan menanggulangi obesitas pada anaknya sering "dikalahkan" oleh perasaan tidak tega. Sama halnya yang ditemukan pada penelitian di Australia, penyebab kurangnya kontrol perilaku anak, dan adanya perbedaan antara pengetahuan dan perilaku orangtua terkait dengan upaya (perilaku) pencegahan obesitas seringkali tidak konsisten (Hesketh et.al, 2005).

\section{Cara Orangtua Mengatur Pola Aktivitas Anak}

Ketika memulai aktivitas pada pagi harinya, beberapa ibu mengatakan kesulitan membangunkan anak mereka dari tidurnya. Bila dilihat komentar dari beberapa ibu, anak laki-laki lebih banyak beraktivitas daripada anak perempuan, ketika anak sudah sampai di rumah. Anak perempuan lebih cenderung kurang bergerak dan melakukan aktivitas yang monoton, bahkan jarang melakukan kegiatan bermain yang mengeluarkan energi. ibu yang memiliki anak laki-laki mengatakan, meskipun gemuk tapi anak mereka aktif dan tidak mengalami hambatan dalam beraktivitas.

Anak laki-laki lebih aktif berolahraga dari pada anak perempuan. Sama halnya yang dikemukakan pada penelitian di Semarang, bahwa ada perbedaan bermakna pada jenis kelamin, anak laki-laki yang berolahraga 1 per minggu lebih banyak dibandingkan perempuan begitu juga dengan lamanya waktu olahraga (Mexitalia et.al, 2005). Walaupun demikian, ibu mengakui anak mereka lambat dalam bergerak dan cenderung malas dikarenakan bobot tubuh yang berlebih. Obesitas cenderung menurunkan aktivitas karena untuk mengurangi kerja anggota tubuh yang harus bekerja lebih berat untuk mengakomodasi kelebihan berat badan, dan terakhir peningkatan masa tubuh memerlukan tambahan untuk melakukan kegiatan yang sama (Syarif, 2003).

Jadwal di sekolah yang padat dan lama, membuat anak-anak jarang nonton TV dan main video game. Apabila sampai di rumah anak-anak cenderung istirahat, lalu mengerjakan tugas-tugas di sekolah. Ada juga anak yang mengikuti les tambahan, ada yang bermain bola, main sepeda, ada juga yang bermalas-malasan. Namun menurut sebagian ibu, ada juga anak yang cenderung banyak menghabiskan waktu bermain video game lebih dari 2 jam ketika pulang sekolah.

Ibu lebih mengetahui aktivitas anak bila di rumah daripada di sekolah. Walaupun demikian ibu mengetahui bahwa anaknya bila di sekolah hanya berolahraga sekali dalam satu minggu, ibu juga menyadari bila di sekolah anak lebih banyak duduk (belajar) daripada bergerak. Di rumah, ibu mengatakan bahwa anak mereka jarang berolahraga. Menurut ibu, jarangnya anak olahraga di rumah karena keterbatasan waktu anak karena sudah banyak menghabiskan waktu di sekolah sehingga ibu terkesan membiarkan anaknya tidak olahraga.

Ibu juga beranggapan bila anak mereka olahraga, membuat nafsu makan anak bertambah, terutama berenang. Anggapan ibu tersebut tentu saja mengakibatkan perlakuan orangtua untuk tidak menganjurkan anak untuk memilih berenang sebagai alternatif olahraga, pada hal dengan berenang akan menghabiskan 288 kalori dan bila tidak di selingi dengan makan yang berlebihan setelah berenang akan menyeimbangkan antara asupan makanan dan keluaran energi. Pada anak obesitas, aktivitas sehari-hari maupun hobi sering berhubungan dengan makan, seperti ungkapan ibu ketika anak berenang diselingi dengan makan makanan yang disediakan di kafe dan pada perjalanan pulang dari berolahraga diikuti dengan makan pizza (Syarif, 2002). Berarti orangtua menganggap 
berenang bukanlah pilihan yang tepat bagi anak.

Ibu hanya mempunyai sedikit pilihan olahraga bagi anak seperti main bola kaki, main sepeda, dan olahraga di sekolah. Bahkan kebanyakan anak-anak minim melakukan olahraga yang dilaksanakan kurang dari 30 menit $(69,8 \%)$, yang masih jauh dari harapan jam olahraga ideal yaitu 180 menit. Kurangnya berolahraga di rumah maupun di sekolah, kegiatan duduk (belajar) yang lebih banyak dari pada kegiatan fisik, bermalasmalasan, bermain play station dalam jangka waktu yang lama menjadikan aktivitas anak cenderung rendah yang dapat memperparah kondisi obesitas. Pada hal anak dengan aktivitas fisik yang rendah menunjukkan risiko 9 kali lebih tinggi untuk terjadi obesitas dibandingkan dengan anak yang memiliki aktivitas tinggi (Yulian, 2006).

Pergi sekolahpun ibu lebih cenderung untuk mengantarkan anak mereka menggunakan kendaraan bermotor. ibu menganggap bila tidak diantar, anak akan kecapean dan berkeringat sehingga mengganggu konsentrasi belajar, walaupun jarak tempuh dari rumah ke sekolah tidak begitu jauh. Cara ibu memperlakukan anak tersebut membuat anak malas dan enggan melakukan aktivitas fisik. Sebagian besar anak diantar oleh orangtua yang menyebabkan meningkatnya risiko obesitas pada anak (Mexitalia et.al, 2005). Padahal dengan jalan kaki ke sekolah menurunkan risiko untuk menjadi obesitas. Pemahaman orangtua yang menganggap anak yang seharian berada di sekolah sudah merasa kelelahan, sehingga orangtua terkesan tidak memaksakan anak untuk beraktivitas / berolahraga.

Ibu memiliki beberapa pilihan dalam menigkatkan aktivitas fisik anak karena aktivitas fisik mempunyai pengaruh yang bermakna terhadap penggunaan energi. Dalam simposium di Surabaya, didapatkan bahwa peningkatan aktivitas pada anak gemuk bisa menurunkan nafsu makan dan meningkatkan laju metabolisme. Anak-anak dianjurkan melakukan aktivitas fisik sedang selama 20-30 menit (Syarif, 2003). Aktivitas fisik disesuaikan dengan perkembangan motorik, kemampuan fisik dan umurnya. Pada anak sekolah dasar, aktivitas lebih tepat dengan memulai keterampilan otot. Selain berenang dan sepak bola, bersepeda, menari, karate, senam, dan basket, dapat dijadikan pilihan olahraga. Pilihan lain dalam memaksimalkan aktivitas sehari-hari adalah berjalan kaki atau bersepeda ke sekolah, naik turun tangga dengan menempati kamar tingkat, menganjurkan bermain di luar rumah, serta mengurangi bermain play station dan nonton televisi.

\section{Kesimpulan}

Kesalahan persepsi ibu dalam penelitian ini adalah ibu menganggap obesitas pada balita adalah normal, bila sudah remaja/dewasa badan bisa kurus sendiri, sehingga keadaan obesitas tidak perlu dikhawatirkan

Beberapa kesalahan persepsi ibu yang mengakibatkan kesalahan dalam mengatur pola makan/perilaku makan pada anak obesitas adalah anggapan ibu bahwa makanan lokal seperti bakso, sate, siomay dan lain-lain tidak termasuk jenis makanan fast food. Ibu selalu mendorong anak untuk tambah porsi makan setelah anak menghabiskan makanannya, sehingga terbentuk pola makan berlebihan pada anak. ibu cenderung menuruti pola makan yang salah pada anak yaitu pola makan berlebihan karena faktor ketidaktegaan, sehingga berdampak pada perlakuan pemberian uang jajan yang besar yang menyebabkan anak mengkonsumsi asupan tinggi kalori di sekolah tanpa diimbangi dengan olahraga/aktivitas yang cukup.

Ibu terkesan tidak memaksakan anak untuk beraktivitas berat/berolahraga di luar sekolah karena menganggap anak sudah cukup kelelahan dengan jadwal padat di sekolah, sehingga berdampak terhadap perlakuan membiarkan anak untuk tidak olahraga. Berenang menurut ibu, bukan pilihan olahraga yang tepat pada anak obesitas, karena setelah berenang memicu rasa lapar pada anak. 


\section{Saran}

Saran-saran yang dapat disampaikan adalah bagi orangtua: 1). Bila mempersiapkan menu sehari-hari, harap dipilih buah dan sayuran dibandingkan makanan cepat saji serta selalu sediakan kudapan yang sehat (batasi pembelian makanan dan minuman yang manis). Resep dan metode memasak yang menggunakan lemak dilakukan sedikit mungkin seperti merebus, kukus, atau memanggang bukan menggoreng atau menggulai (santan), 2). Kebiasaan yang kurang baik sejak dini seperti mendorong anak untuk tambah, bila anak sudah cukup kenyang tidak perlu dilakukan. Ibu diharapkan lebih mengontrol porsi makan yang sesuai bagi anak, 3). Tidak memberikan uang jajan pada anak ketika di sekolah, melainkan membekali anak dengan makanan yang rendah kalori dan lemak serta tinggi serat, 4). Anak perlu didampingi dalam beraktivitas seperti membuat jadwal kegiatan keluarga yang teratur seperti jalan-jalan, bermain bola bersama, dan kegiatan di luar rumah lainnya (out door).

Kepada sekolah: 1). Diharapkan meningkatkan kegiatan fisik agar siswa lebih beraktivitas seperti mengadakan kegiatan belajar matematika out door dengan menghitung pohon atau lomba mengumpulkan batu, sehingga aktivitas lebih menyenangkan, 2). Pengawasan rutin terhadap jajanan kantin dengan larangan menyediakan makanan dan minuman fast food/junk food perlu dilakukan dengan menyediakan makanan serba sayur seperti pecal, lotek dan aneka juice. Kerja sama dengan dinas kesehatan (ahli gizi) melatih petugas kantin untuk menyediakan makanan/jajanan sehat (kantin sehat), 3). Bekerjasama dengan Dinas Kesehatan (ahli gizi) dalam hal penyuluhan pencegahan dan penanggulangan obesitas pada saat berkumpulnya orangtua/ibu seperti pada saat pengambilan raport siswa dan menetapkan hari-hari kunjungan tertentu untuk konsultasi di pojok gizi puskesmas/di ruangan UKS. Sebelumnya bekoordinasi dengan pihak sekolah dan petugas kesehatan, 4). Mengadakan acara makan bersama minimal 1 bulan sekali dengan tujuan melatih dan mendidik siswa untuk memilih dan mengkonsumsi makanan yang sehat (rendah lemak, kalori dan kolesterol).

\section{Daftar Pustaka}

Adinigsih, S., Ukuran Pertumbuhan dan Status Gizi Remaja Awal Dalam Sandjaja, Abas B.J., Imam S., Gustina S., Rodiamdi, Budi H., Prosiding Kongres Nasional Persagi dan Temu Ilmiah XII, 2002, 94-110.

Baugham, A.E., Chamberlin, E.A., Deeks, C.M., Power, S.W., Whitaker, R.C. (2006), Maternal Perception of Overweight Preschool Children. Journal of The American Academy of Pediatric, Volume 106 no. 6, 2000. page 1380-1386.

Behrman, Kliegman, Arvin, (2000), Ilmu Kesehatan Anak Edisi 15 Bahasa Indonesia, Penerbit Buku Kedoteran EGC, Jakarta.

Dwiriani, C.M., Risma, K.D., Efendi, Y.H. (2007) Pelajar Gemuk Makan Lebih Banyak Dibandingkan Pelajar Berstatus Gizi Normal Dalam International Seminar " Obesity as Poverty-Related Emerging Nutrition Problem in Indonesia",Abstrak Book, Yogyakarta.

Eckstein, K.C., Mikhail, L.M., Ariza, A.J., Thomson, S., Millard, S.C., Binns, H.J. (2006), Parent Perception of Their Child's Weight and Health, Journal of The American Academy of Pediatrics, Vol. 117, page 681690.

Hesketh, K., Waters, E., Green, J., Salmon, L., Williams, J. (2005), Healthy Eating, Activity and Obesity Prevention : a Qualitative Study in Australia, Journal Health Promotion International, Vol.20 No.1, page 19-26.

Hidayati, N.S., Irawan, R., Hidayat, B. (2005), Obesitas Pada Anak, Bagian Ilmu Kesehatan Anak, Fakultas Kedokteran Universitas Airlangga, Surabaya.

Huriyati, E. (2006), Studi Kohort Prevalensi Obesitas Siswa siswi SLTP Kota Yogyakarta, Jurnal Gizi Indonesia Fakultas Kedokteran Universitas Gadjah Mada, Yogyakarta Edisi Juli Vol 3 No. 1. 
Julia, M. (2008), The Impact of SocioEconomic Status on The Risk of Malnutrition and Overweight in Indonesian Children, Penerbit Pd. Hidayat, Yogyakarta.

Maffeis, C., Provera, S., Filippi, L., Sidoti, G., Schena, S., Pinelli, L., Tato, L. (2000), Distribution of Food Intake As A Risk Fakctor For Childhood Obesity, International Journal of Obesity, Macmillan Publisher Ltd, Vol 24:75-80.

Mahdiah (2004), Prevalensi Obesitas dan Hubungan Konsumsi Fast Food Dengan Kejadian Obesitas Pada Remaja SLTP Kota dan Desa Di Daerah Istimewa Yogyakarta, Jurnal Gizi Klinik Indonesia, Vol.1 No.2 ; 7785 .

McKenzie, J.F., Pinger, R.R., Kotecki, J.E (2007), An Introduction to Community Health, Edisi 4, Penerbit Buku Kedokteran EGC, Jakarta.

Mexitalia, M., Susanto, JC., Farzah, Z., Hardian, (2005), Hubungan Pola Makan dan Aktifitas Pada Anak Dengan Obesitas Usia 67 Tahun Di Semarang, Journal M. Med Indonesia, Vol 40 No.2.

Moleong, L.J. (2008), Metodologi Penelitian Kualitatif, Edisi Revisi, Penerbit PT. Remaja Rosdakarya, Bandung.

Morse, J.M. (1992), Qualitative Health Research, Sage Publications International and Profesional Publisher Newbury Park London, New Delhi.

Mulyana, D. (2007), Ilmu Komunikasi Suatu Pengantar, PT. Remaja Rosdakarya, Bandung.

Padmiari, I.A.E. (2002), Prevalensi Obesitas dan Konsumsi Fast Food Sebagai Faktor
Terjadinya Obesitas Pada Anak SD di Kota Denpasar Provinsi Bali, Tesis, Universitas Gadjah Mada, Yogyakarta.

Pampang, E. (2007), Asupan Energi, Aktivitas Fisik, Persepsi Orangtua dan Obesitas Siswa SMP, Tesis, Universitas Gadjah Mada, Yogyakarta.

Podojoyo, (2005), Pola Komsumsi Makan di Luar Rumah Sebagai Faktor Risiko Terjadinya Obesitas Pada Remaja SMP di Kota Palembang, Jurnal Gizi Klnik Indonesia, Vol.3 No.2, November 2006; 46-55.

Sarwono, S. (2007), Sosiologi Kesehatan Beberapa Konsep Beserta Aplikasinya, Gajah Mada University Press, Yogyakarta

Subardja, D. (2005), Obesitas Pada Anak : Penyakit Masa Depan Yang Terabaikan, Dalam Naskah Lengkap Pertemuan Ilmiah Nasional Dietetic II Asosiasi Dietesin Indonesia Cabang Jawa Barat, Bandung.

Syarif, D.R. (2003), Childhood Obesity : Evaluation and Management, Dalam Naskah Lengkap Nasional Obesity Symposium II, Editor: Adi. S, dkk, Surabaya.

Undang-Undang Kesehatan 1992 (2000), Undang-Undang No.23 Tahun 1992, Sinar Grafika Offset, Jakarta.

Widjajanto, P.H. (1998), Hubungan Antara Persepsi Orang Tua Tentang Kegemukan Anak dengan Kejadian Kegemukan Pada Siswa SD di Kotamadya Yogyakarta, Tesis, Universitas Gadjah Mada Yogyakarta.

Yulian, E. (2006), Lama Bermain Play Station Sebagai Faktor Risiko Terjadinya Obesitas Pada anak Usia Sekolah Dasar, Tesis, Universitas Gadjah Mada, Yogyakarta 